\title{
Burning water and other myths
}

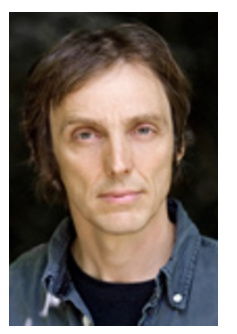

We will never stem the idea that water can act as a fuel, says Philip Ball.

Philip Ball

Have you heard the one about the water-powered car? If not, don't worry - the story will come round again. And again. Crusaders against pseudoscience can rant and rave as much as they like, but in the end they might as well accept that the myth of water as a fuel is never going to go away.

Its latest manifestation comes from Pennsylvania, where a former broadcast executive named John Kanzius claims to have found a way to turn salt water into a fuel. Expose it to a radiofrequency field, he says, and the water burns. There are videos to prove it, and scientists and engineers have apparently verified the result.

"He may have found a way to solve the world's energy problems," announced one local TV presenter. "Instead of paying four bucks for gas, how would you like to run your car on salt water?" asked another. "We want it now!" concludes a wide-eyed anchorwoman. Oh, don't we just.

"I'd probably guess you could power an automobile with this eventually," Kanzius agrees. Water, he points out, is "the most abundant element [sic] in the world."

It's easy to scoff, but if the effect is genuine then it is also genuinely intriguing. Plain tap water apparently doesn't work, but test tubes of salt water can be seen burning merrily with a bright yellow flame in the radiofrequency field. The idea, articulated with varying degrees of vagueness in news reports when they bother to think about such things at all, is that the field is somehow dissociating water into oxygen and hydrogen. Why salt should be essential to this process is far from obvious. You might think that someone would raise that question.

But no one does. No one raises any questions at all. The reports offer a testament to the awesome lack of enquiry and critical thought that makes news media everywhere quite terrifyingly defenceless against bogus science.

\section{Men in white coats}

And it's not just the news media. There is footage of labs and people in white coats and engineers testifying how amazing the result is, and no one seems to be wondering about how this amazing phenomenon works. As a rule, it is always wise to be sceptical of people claiming great breakthroughs without the slightest indication of any intellectual curiosity on their part.

This is not in itself to pass any judgement on Kanzius's claims; as ever, they must stand or fall on the basis of careful experiment. But the most fundamental, the most critical question about the whole business leaps out at you so immediately that its absence from these reports, whether they be on Pennsylvania's JET-TV or on PhysOrg.com, is staggering. Can you get more energy out than you put in?

I can answer that right now: no. You start with water, you break it apart into its constituent elements (hydrogen and oxygen), and then you recombine them by burning. Yes you can do that. Hydrogen, indeed, is the promised fuel of the new clean energy economy. But making hydrogen from water takes more energy than you can ever recover from burning it. Extracting net energy from this total cycle is impossible, if you believe in the first and second laws of thermodynamics. Otherwise, you have the basis of a perpetual-motion machine.

But 'energy for free' enthusiasts don't want to know about thermodynamics. Thermodynamics is a killjoy. Thermodynamics is like big government or big industry, always out to squash innovation. Thermodynamics is the enemy of the Edisonian spirit of the backyard inventor.

\section{The final verdict}

Here, however (for what it is worth) is the definitive verdict of thermodynamics: water is not a fuel. It never has been one, and it never will be one. Water does not burn. Water is already burnt - it is spent fuel. It is exhaust.

Oh, it feels better to have said that, but I don't imagine for a moment that it will end these claims of 'water as fuel'. Why not? Because water is a mythical substance. Kanzius's characterization of water as an 'element' attests to that: yes, water is of course not a chemical element, but it will never shake off its Aristotelian persona, because Aristotle's four classical elements (earth, air, fire and water) accord so closely with our experiential relationship with matter.

Indeed, one of the most renowned 'water as fuel' prophets, the Austrian forester Viktor Schauberger, whose experiments on water flumes and turbulence led to a most astonishing history that includes audiences with Hitler and Max Planck and water-powered Nazi secret weapons, claimed that water is indeed in some sense elemental and not 'compound' at all.

And water has always looked like a fuel — for it turned the water wheels of the Roman empire, and still drives hydroelectric plants and wave turbines all over the world. No wonder it seems energy-packed, if you don't know thermodynamics. 
Water, we are told, can unlock the hydrogen economy, and holds untold reserves of deuterium for nuclear fusion. Here is nuclear pioneer Francis Aston on the discovery of fusion in 1919: "To change the hydrogen in a glass of water into helium would release enough energy to drive the Queen Mary across the Atlantic and back at full speed." Was it a coincidence that cold fusion involves the electrolysis of (heavy) water, or that the controversial recent claims of'bubble fusion' took place in water? Of course not.

Burn, baby, burn

As for 'burning water', that has a long history in itself. It is what the alchemists called alcohol when they first isolated it, and they were astonished by a water that would ignite. One of the recent sightings of 'water fuel' happened 11 years ago in Tamil Nadu in India, where a chemist named Ramar Pillai claimed to power a scooter on 'herbal petrol' made by boiling herbs in water at a cost of one rupee (three cents) a litre. Pillai was granted 20 acres of land by the regional government to cultivate his herbal additive before he was rumbled.

And then there is poor Stanley Meyer, inventor of the 'water-powered car'. Meyer just wanted to give people cheap, clean energy. But the oil companies clearly couldn't have that and so harassed and intimidated him(the internet says so it must be true). In 1996 he was found guilty of "gross and egregious fraud" by an Ohio court. He died in 1998 after eating at a restaurant; the coroner diagnosed an aneurysm, but the conspiracy web still suspects he was poisoned.

It's not easy to establish how Meyer's car was meant to work, except that it involved a fuel cell that was able to split water using less energy than was released by recombination of the elements. Dig a little deeper and you will soon find the legendary Brown's gas — a modern chemical unicorn to rival phlogistion - in which hydrogen and oxygen are combined in a non-aqueous state called 'oxyhydrogen', in the same proportions in which they are found in water (2:1). Brown's gas was allegedly used as a vehicle fuel by its discoverer, Australian inventor Yull Brown.

I think Kanzius must be making Brown's gas. How else can you extract energy by burning water, if not via a mythical substance? Unlike Stan Meyer's car, this story will run and run.

Visit our waterandothermyths.html">newsblog to read and post comments about this story. 